(C) 2017

Томілін О. О., доктор економічних наук, професор

Полтавська державна аграрна академія

\title{
ОСОБЛИВОСТІ ФОРМУВАННЯ МІЖГАЛУЗЕВИХ ЗВ'ЯЗКІВ ТА ЇХ ВПЛИВ НА СТРУКТУРНУ ПОЛІТИКУ В АПВ
}

\section{Рецензент - доктор економічних наук, професор Х. 3. Махмудов}

У статті здійснено системний аналіз сучасного стану міжгалузевих економічних відносин у системі агропромислового виробництва, розкрито специифіку формування та розвитку міжгалузевих економічних зв'язків в аграрній сфері економіки та їх вплив на структурну політику агропромислового виробництва, обтрунтовано основні чинники системного утворення міжгалузевих економічних відносин у агропромисловому виробництві. Структурна політика розглядається як багатопланове та багаторівневе поняття, яке відображає співвідношення різних взаємопов'язаних $i$ взаємообумовлених елементів економічних систем. Зроблено висновок щуодо основних механізмів коригування структурної політики: реалізацію комплексних иільових програм, вільне иіноутворення, конкуренцію, нагромадження та перелив капіталу з однісї галузі в іншу. Визначено, щчо основними цілями структурно-організаційного інструменту регулювання є: митно-тарифні; соціально-психологічні; ринково-ціноутворюючі; фінансово-кредитні; інноваціийно-інвестииійні.

Ключові слова: міжгалузеві зв'язки, структурна політика, агропромислове виробництво, фактори системного утворення, ієрархічна модель рівнів.

Постановка проблеми. Дослідження глибинних процесів міжгалузевих економічних відносин $\epsilon$ важливим елементом для розуміння тенденцій та напрямів розвитку національної економіки. У нинішніх умовах соціально-економічного і фінансово-економічного розвитку держави базовою метою формування майбутньої моделі економіки України $є$ активна та цілеспрямована структурна політика. Потреба вивчення структурної політики зумовлена необхідністю комплексного наукового обгрунтування концепції подальшого розвитку як агропромислового виробництва (АПВ), так і національної економіки в цілому. Структурна політика повинна базуватися на основі оптимальних темпів зростання різних секторів та галузей національної економіки 3 дотриманням макроекономічних пропорцій у сфеpax, пов'язаних з АПВ.

Аналіз останніх досліджень і публікацій, у яких започатковано розв'язання проблеми. Теоретико-методологічні основи міжгалузевих відносин у АПВ досліджені такими вченими як: Б. В. Бойко, В. Л. Валентиновим, Т. В. Гагалюком, П. І. Гайдуцьким, С. М. Квашею, І. Г. Кириленком, М. Ф. Кропивком, М. Й. Маліком， В. Я. МесельВеселяком, . П. Мильком, Ю. О. Нестерчук, П. Т. Саблуком, В. П. Ситником, О. М. Шпичаком та іншими.

Вдосконалення процесу структурних перетворень у національному господарстві, аналіз взаємодії взаємопов'язаних галузей і сфер, теоретичних аспектів структурної перебудови грунтовно викладені в наукових працях цілої низки відомих вчених-практиків: Л. І. Абалкіна, В. Г. Андрійчука, Л. Д. Вардомського, А. С. Гальчинського, Б. М. Данилишина, М. І. Долішнього, Я. А. Жаліло, М. О. Кобзистого, І. І. Кукурудзи, Ю. О. Лупенка, I. О. Лютого, Б. Й. Пасхавера, Г. Г. Михальченка, Л. М. Шаблистої та інших. Незважаючи на глибину дослідження наукових основ становлення та розвитку міжгалузевих економічних відносин в агропромисловому виробництві, визначення міжгалузевих виробничих зв'язків, особливо у сільському господарстві в період ринкового реформування, поза увагою залишаються питання структурної перебудови в формуванні міжгалузевих економічних відносин у агропромисловому виробництві.

Метою досліджень $\epsilon$ наукове обгрунтування теоретико-методологічних засад змісту структурних чинників, визначення їх місця і ролі в аграрній політиці та аграрному секторі економіки й розроблення практичних рекомендацій щодо формування ефективних пропорцій міжгалузевого економічного механізму стимулювання агропромислового виробництва України.

Найважливішим невирішеним завданням, який стримує розвиток аграрного сектору економіки, $є$ нееквівалентність обміну ресурсами на вході та на виході із системи АПВ, а також не відпрацьованість взаємодії між взаємопов'язаними і взаємообумовленими структурними елементами агропродовольчої сфери.

Матеріали і методи досліджень. Для вирішення поставлених у науковій статті завдань використано базові методи наукового пізнання. 


\section{ЕКОНОМІКА}

Серед них: абстрактно-логічний (теоретичні узагальнення та формулювання висновків); монографічний (під час дослідження теоретичних $\mathrm{i}$ методологічних основ міжгалузевих економічних відносин в агропромисловому виробництві та аналізі діяльності окремих агроформувань).

Результати досліджень. До методологічних принципів міжгалузевих відносин в агропромисловому виробництві доцільно віднести: посилення маркетингової орієнтації, інтеграційні процеси на підприємствах, поглиблення спеціалізації виробництв, поширення нових видів сільськогосподарської продукції, інвестиційну привабливість, територіальну наближеність до європейських продовольчих ринків, наявність кваліфікованої робочої сили. Основними напрямами розвитку сільського господарства, як головної ланки агропромислового виробництва, є: швидкий, випереджувальний розвиток виробничих галузей, прискорення темпів розвитку переробної промисловості, створення сучасної бази щодо збереження та переробки сільськогосподарської продукції, впровадження безвідходних технологій. Деякі вчені стверджують, що одним 3 головних чинників розвитку національного АПВ та формування в ньому адекватного виробничого потенціалу є удосконалення взаємозв'язків між промисловістю, яка забезпечує аграрний сектор необхідними засобами і предметами праці та переробляе сільськогосподарську сировину і сільським господарством як специфічною галуззю економіки [5]. Поглиблення міжгалузевих економічних зв'язків є закономірністю суспільного поділу праці. Як підкреслює П. І. Гайдуцький, механізмом розвитку і функціонування агропромислового виробництва $\epsilon$ розвиток і функціонування міжгалузевих зв'язків, які відображають як загальну закономірність розвитку і взаємодії продуктивних сил і виробничих відносин, так i територіальні, і галузеві відмінності їх прояву [2]. На думку Б. В. Бойко, для формування міжгалузевих економічних відносин необхідним $\epsilon$ забезпечення умов для розвитку процесів спеціалізації, концентрації, кооперації в сільському господарстві та агропромислової інтеграції, стимулювання утворення інтеграційних об'єднань [1]. Функціонування і розвиток міжгосподарських зв'язків має базуватися на наступних принципах: рівноправності договірних сторін, обов'язковості та відповідальності партнерів відповідно до законодавства та плану, комплексності, динамічності, пропорційності, ритмічності та синхронності, що забезпечують оптимальний режим роботи всіх ланок єдиного організа- ційно-технологічного ланцюга інтегрованого виробництва, зацікавленості в розвитку і зміцненні виробничих зв'язків, підвищення ефективності кінцевих результатів інтегрованого виробництва, контролі (взаємне і з боку вищестоящих організацій) [6].

Структурна перебудова національної економіки пов'язана зі структурними трансформаціями кон'юнктури ринку та механізмом впливу на структурну політику національного господарства. Отже, механізмом структурних перетворень можна назвати перетворення в структурі показників міжгалузевих економічних відносин між державою, домогосподарствами, холдинговими структурами, корпораціями тощо, які дають змогу подолати диспропорції, які виникають між окремими сферами, галузевою структурою національної економіки країни, стабілізацією і зростанням виробництва. Цілісність агропромислового виробництва обумовлене зростанням технологічної взаємодії галузей національної економіки, системної взаємодії міжгалузевих економічних зв'язків. Саме через запровадження механізму справедливого розподілу доходу та механізму вільного ціноутворення на продукцію аграрної сфери можливо нормативне забезпечення рівня рентабельності виробництва агропромислового виробництва. Згідно зі «стандартами» економічної науки, структурна політика визнається спрямованою діяльністю держави [3].

Чинники системного утворення міжгалузевих відносин нами представлено на рисунку 1.

Як основні структурні чинники, на які сфокусовані напрями аграрної політики, можна виділити: формування галузевого розвитку аграрного сектору, забезпечення економічних інтересів учасників ринку, визначення співвідношення обсягів виробництва рослинницької і тваринницької продукції.

У результаті проведеного дослідження нами пропонується розглядати рівні структурної політики у динаміці на нижче наведених ієрархічних рівнях:

І рівень - галузь у світовій економіці; II рівень - галузь у національній економіці; III рівень структура галузей (підгалузей); IV рівень - структура споживчого ринку; V рівень - структура переробної (харчової) промисловості; VI рівень - структура сільгоспвиробників за категоріями; VII рівень - структура собівартості сільськогосподарської продукції.

Ієрархічну модель рівнів структурної політики у динаміці нами відображено на рисунку 2. 


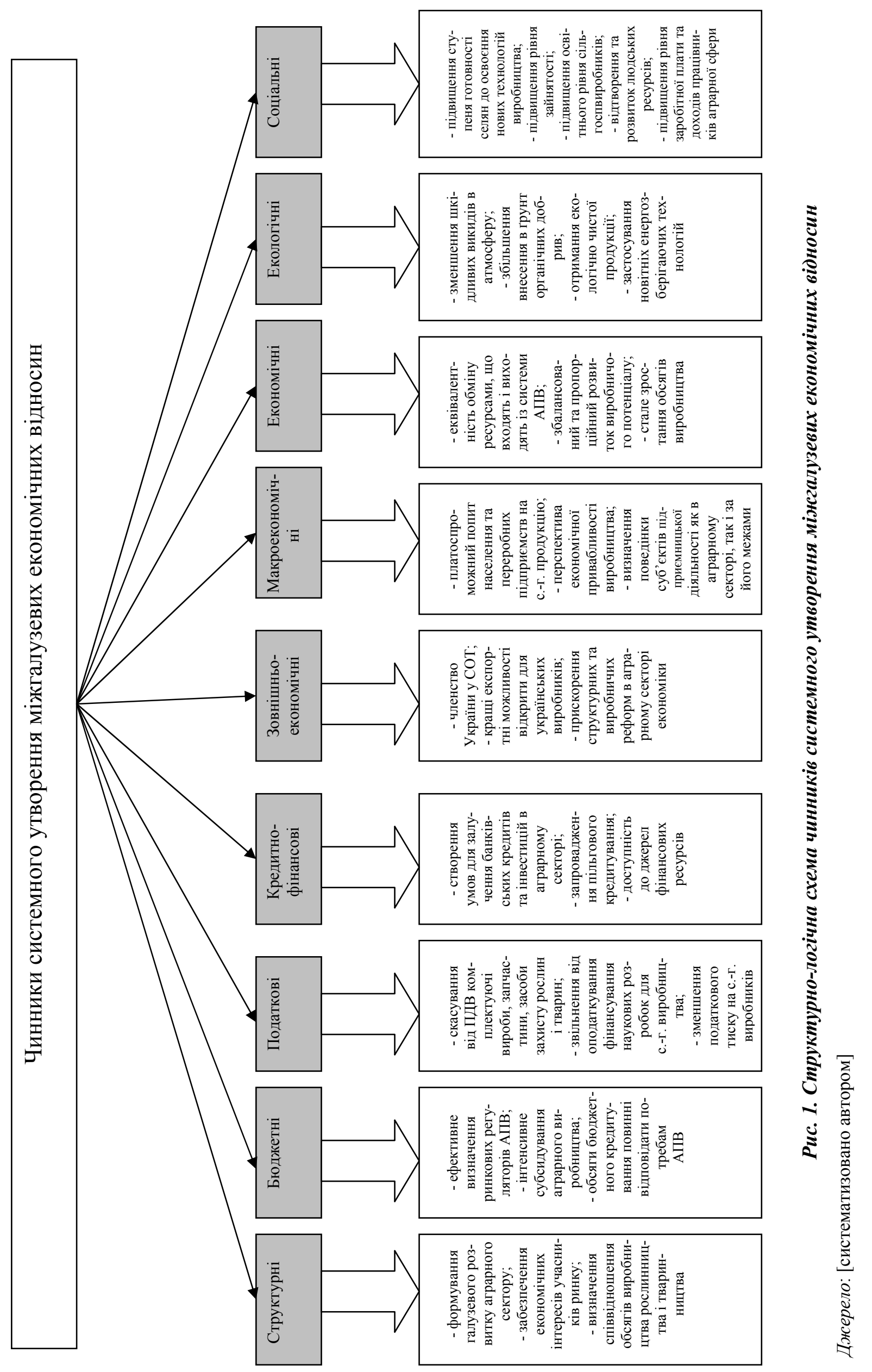




\section{EKOHOMIKA}

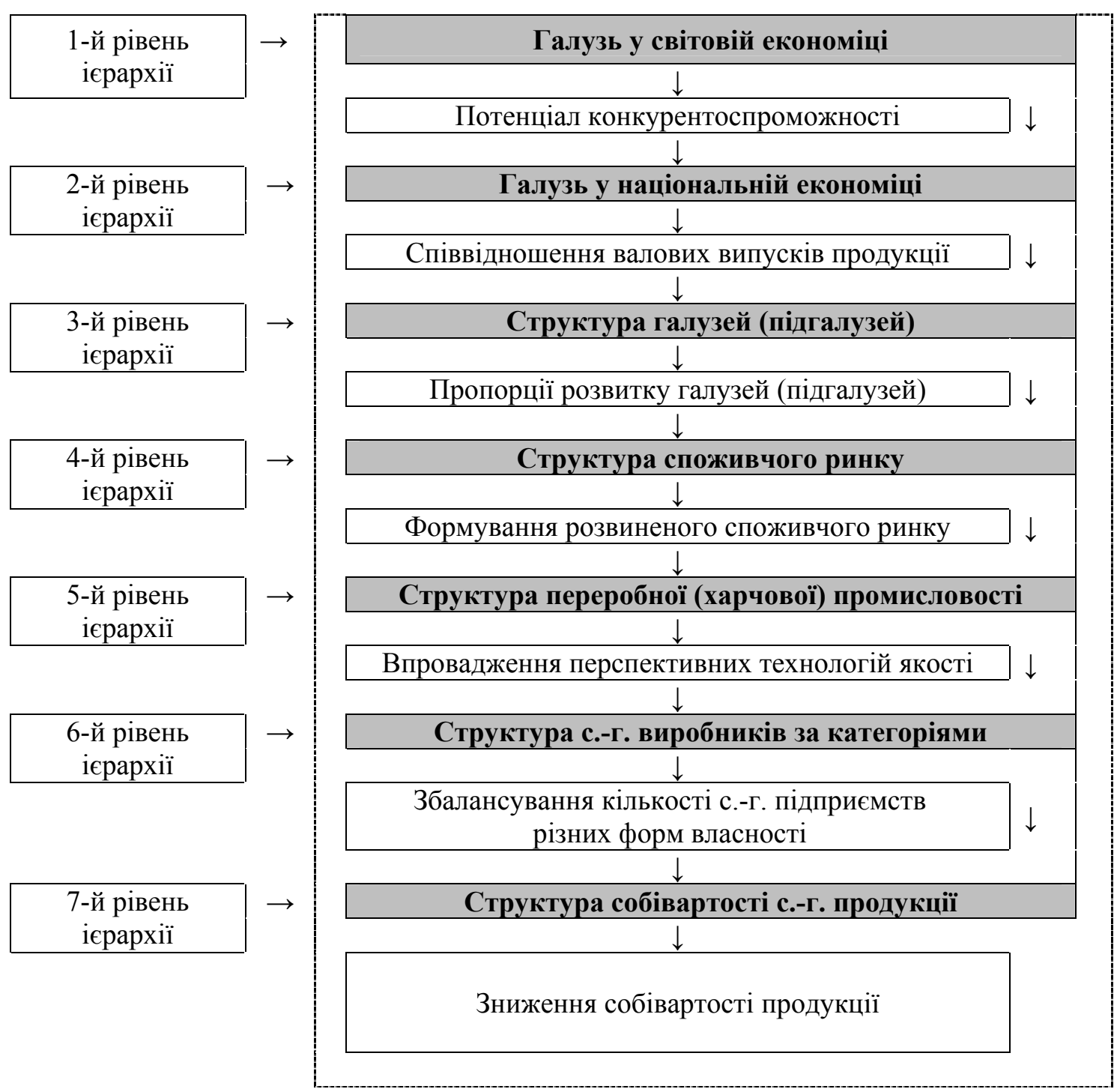

Рис. 2. Ісрархічна модель рівнів структурної політики

Джерело: [розробка автора]

Перший (найвищий) рівень ієрархії відображає потенціал конкурентоспроможності галузі окремо взятої країни у світовій економіці; другий показник враховує співвідношення валового випуску продукції з урахуванням частки кожної галузі в економіці країни; третій рівень ієрархії відображає пропорції розвитку галузей (підгалузей) агропромислового виробництва; четвертий показник ієрархії відображає показники щодо ланцюгів реалізації товарів з метою задоволення потреб населення споживчими товарами; п'ятий рівень ієрархії враховує способи формування і забезпечення продуктами харчування населення сільських і міських районів держави, зокрема через поліпшення галузевої структури харчової промисловості; шостий рівень ієрархії передбачає аналіз змін у структурі виробництва сільськогосподарської продукції за категоріями виробників; сьомий рівень ієрархії (останній рівень) направлений на дослідження структури собівартості продукції шляхом поділу витрат на матеріальні та нематеріальні з метою аналізу конкурентоспроможності товару окремого підприємства. Таким чином, запропоновані нами рівні структурних чинників поширюються за охопленням від структури матеріальних і нематеріальних витрат у собівартості на мікрорівні, далі на мезорівень - змін у кількості виробників валової продукції сільського господарства за переліком галузей та підгалузей, що пов'язані з сільським, лісовим та рибним господарством і далі до макрорівня, тобто частки валової продукції і валової доданої вартості окремих галузей у структурі національного і світового господарства [4].

До основних завдань структурної політики в агропромисловому виробництві в нинішніх ринкових умовах господарювання можна віднести: 


\section{ЕКОНОМІКА}

продовження політики модернізації виробництва i набуття технологічних переваг вітчизняних відносно зарубіжних товаровиробників, залучення державних програм розвитку переважно тваринницьких галузей на основі ринкових інструментів підтримки, формування ефективних еквівалентних макроекономічних пропорцій у сфері структурних ланок підприємств агропромислового виробництва, зменшення залежності аграрної економіки від імпорту товарів та виробничих ресурсів.

\section{БІБЛІОГРАФІЯ}

1. Бойко Б. В. Теоретичні основи формування міжгалузевих відносин в АПК / Б. В. Бойко // Наука й економіка. - 2009. - Т. 2. - №3 (15). C. $125-128$.

2. Гайдуц̧кий П. И. Межотраслевые связи в агропромышленном комплексе / П. И. Гайдуцкий // Вища школа. - К., 1988. - 192 с.

3. Енциклопедія державного управління у 8 т. - Структурна політика НАДУ при Президентові України ; [голова наук.-ред. кол. Ю. Б. Ковбасюк]. - Т. 4: Галузеве управління / М. М. Іжа, В. Г. Бодров // наук.-ред. колегія. - К. : НАДУ, 2011. - С. 611-613.
Висновок. Наші дослідження свідчать, що до економічних інструментів регулювання міжгалузевих економічних відносин у агропромисловому виробництві необхідно віднести: структурноорганізаційні, фінансові, цінові та податкові. Удосконалення структурної політики в агропромисловому виробництві шляхом розробки економічного та організаційного механізмів регулювання міжгалузевих зв'язків сприятиме підвищенню ефективності функціонування всіх галузей і сфер агропромислового виробництва.

4. Томілін О.О. Формування міжгалузевих зв'язків агропромислового виробництва та їх вплив на структурну політику бурякоцукрового підкомплексу [Текст] : автореф. дис...д.е.н.: 08.00.03 / О. О. Томілін. - К. : Нац. акад. агр. наук України, Нац. наук. цент «Ін-т аграр. економіки», 2015. - 39 с.

5. Трегобчук В. М. Економічні проблеми відтворення і модернізації ресурсного потенціалу АПК / В. М. Трегобчук // Економіка АПК. 1999. - №1. - С. 54-58.

6. Фролов В. И. Экономический механизм межхозяйственных связей в АПК / В. И. Фролов // Агропромиздат. - М., 1989. - 144 с. 